\title{
SERUPA TAPI TAK SAMA \\ ANTARA VERBA SURU DAN YARU
}

\author{
Inu Isnaeni Sidiq \\ Fakultas lmu Budaya Universitas Padjadjaran \\ inu.isnaeni.sidiq@unpad.ac.id \\ Erlina Zulkifli Mahmud \\ Fakultas lmu Budaya Universitas Padjadjaran \\ erlina@unpad.ac.id \\ Taufik Ampera \\ Fakultas lmu Budaya Universitas Padjadjaran \\ taufik.ampera@unpad.ac.id
}

\begin{abstract}
Abstrak
Penelitian ini membahas perbedaan struktur dan makna pada penggunaan verba bersinonim suru dan yaru dalam bahasa Jepang. Metode yang digunakan dalam penelitian ini adalah metode deskriptif dan juga mencoba mennyulih verba suru dan yaru dalam berbagai macam jenis kalimat untuk mengetahui perbedaan dan persamaannya baik secara struktur maupun semantis. Hasil analisis menunjukkan bahwa terlepas dari kebersinoniman kedua verba ini dalam makna' melakukan sebuah perbuatan', penulis menemukan beberapa ciri khas struktur dari masing - masing verba pada saat mengisi posisi predikat sebuah kalimat yang sama. Selain itu, penulis juga menemukan makna verba yaru yang tidak ditemukan pada kamus-kamus referensi yang ada yaitu 'mengirimkan seseorang untuk melakukan sesuatu' yang tidak ditemukan pada penggunaan verba suru. Terlepas dari kebersinoniman kedua verba, hasil peneltian ini menunjukkan bahwa baik verba suru maupun yaru memiliki kekhasan secara struktur dan makna sehingga meskipun bersinonim bukan berarti kedua verba tersebut selalu dapat saling menyulih.
\end{abstract}

Kata kunci: Sinonim, sulih, struktur,makna

\begin{abstract}
The research discussed about the difference between the verb suru and yaru in Japanese language structurally and semantically. Descriptive analysis is used as methodology and susbtitution between the verb suru and yaru is conducted to examine whether both verbs can susbtitute each other in the same sentence and construct an exactly same meaning or not. Through this research we found that despite of similar meaning of the two verbs, We found that each verbs has different characteristic both semantically and structurally in some sentences. We also found a new variant of meaning which is "to send someone to perform certain duty to a certain place" for the verb yaru which can't be constructed by the verb suru. As a summary, this research showed that despite of its similarities, it doesn't mean that both verbs can always substitute each other and constitute the same meaning in all kind of sentences.
\end{abstract}

Keywords: synonym, substitution, structure, meaning 


\section{PENDAHULUAN}

Bahasa adalah sarana pokok yang digunakan oleh manusia untuk berkomunikasi dengan tujuan untuk menyampaikan ide atau pesan kepada orang lain. Walaupun bahasa pada dasarnya memiliki fungsi yang sama, tetapi setiap bahasa memiliki ciri khasnya masing-masing. Kekhasan tersebut bisa dilihat dari segi tata bahasa sebagai sebuah kesatuan, maupun kekhasan dari setiap kelas kata yang menjadi unsur pembentuk kalimat itu sendiri. Sebut saja verba sebagai salah satu contohnya. Verba bahasa Jepang memiliki karakter yang khas karena sering mengalami perubahan bentuk atau konjugasi yang dalam bahasa Jepang sendiri biasa disebut dengan istilah doushi no katsuyou. Berdasarkan tipe perubahannya, verba bahasa Jepang dikklasifikasikan menjadi tiga jenis, yakni ;verba kelompok I atau dalam bahasa Jeoang disebut godan doushi, verba kelompok II ichidan doushi, dan verba kelompok III atau biasa disebut dengan istilah henkaku katsuyou doushi. Dari ketiga jenis verba tersebut, verba yang paling banyak ditemukan pemakaiannya adalah verba kelompok III, yaitu sa-henkaku doushi suru. Hal ini dikarenakan oleh banyaknya pemakaian verba suru yang digunakan sebagai verbalisator kelas kata yang lain seperti nomina (konkret dan abstrak), maupun adjektiva. Selain kedua kelas kata itu, verba suru juga sering digunakan untuk memverbalisasi onomatope yang menunjukkan kondisi atau keadaan sebuah benda atau hal, yang berhubungan dengan perasaan (gitaigo).

Selain pemakaiannya yang sangat produktif, secara semantic verba suru juga memiliki sinonim yang secara struktur maupun makna hampir sama, yakni verba yaru yang termasuk ke dalam kategori verba kelompok I. Walaupun bersinonim, bukan berarti kedua verba tersebut dapat selalu saling sulih satu sama lain dalam setiap kalimat. Ada kalanya substitusi di antara kedua verba tidak berterima secara gramatikal seperti dalam kalimat di bawah ini.

1. a. Shigoto ga owattara, konya ippai yarimashou! pekerjaan Nom selesai, malam ini segelas melakukan

"Kalau pekerjaan sudah selesai, malam ini mari kita minum (minuman keras)!"

b. *shigoto ga owattara, konya ippai shimashou! (tidak berterima) pekerjaan Nom selesai, malam ini segelas melakukan

2. a. Shinpai o suru.

kekhawatiran Acc melakukan

"Merasa khawatir"

b. *Shimpai o yaru (tidak berterima)

kekhawatiran Acc melakukan

Hal seperti ini tentu saja menjadi kesulitan tersendiri bagi pembelajar bahasa Jepang asing yang tidak dibekali intuisi yang akan secara alami memilah kapan kedua verba tersebut bisa saling sulih atau tidak seperti halnya seorang penutur asli bahasa Jepang. Oleh karena itu, penelitian ini bertujuan untuk menjelaskan prasyarat linguistik dapat saling sulihnya verba suru dan verba yaru baik secara struktur gramatikal maupun semantik. 
Dalam penelitian kali ini penulis menggunakan dua penelitian terdahulu sebagai landasan yaitu teori makna dan pemakaian verba suru dan yaru yang ditulis oleh Nita (1993) dan teori tentang substitusi antara verba suru dan yaru yang ditulis oleh Ogawa (1982). Nita (1993: 524-525) membagi makna verba suru menjadi tujuh belas kategori makna, yaitu; melakukan aktifitas atas dasar kehendak sendiri, melakukan perbuatan terhadap orang lain, melakukan pekerjaan Bersama - sama, menimbulkan gejala fisiologis, memakai sesuatu di badan, melakukan peranan atau profesi tertentu, membuat seseorang melalukan sebuah pekerjaan, memutuskan sebuah perihal, mengubah seseorang atau sesuatu menjadi sesuatu yang lain, mengubah keadaan atau kondisi sebuah benda, merasakan hal-hal yang tertangkap oleh pancaindera, memperlihatkan kualitas sesuatu, menunjukkan nilai sebuah benda atau berlalunya satu kurun waktu tertentu, keadaan tepat sebelum sesuatu terjadi, mempersepsikan sesuatu berbeda dengan kenyataannya, memposisikan diri lebih rendah dari orang lain, serta makna mengasumsikan atau berandai-andai. Selanjutnya, Nita (1993:524-525) membagi makna verba yaru menjadi sepuluh kategori, yaitu ; menyuruh seseorang ke suatu tempat untuk melalukan sesuatu yang kita inginkan, pergi membawa sesuatu ke suatu tempat, mengarahkan pandangan ke arah tertentu, memberikan sesuatu kepada orang yang lebih muda atau makhluk hidup lainnya, melakukan aktifitas tertentu (termasuk makan dan minum), menyakiti atau menimbulkan kerugian, menjalani hidup, menderita penyakit, melakukan sesuatu untuk orang yang lebih muda atau makhluk hidup lainnya, memutuskan, bertekad untuk melakukan sesuatu.

Sebenarnya Nita (1993) sudah membagi makna dari verba suru dan yaru dengan sangat komprehensf dan terperinci. Akan tetapi, pembagian makna menurut Nita masih terlalu bercampur sehingga penulis berpendapat perlu pembagian yang lebih spesifik antara mana yang termasuk ke dalam makna leksikal, dan mana yang termasuk ke dalam makna gramatikal dari masing-masing verba tersebut. Kemudian Nita juga belum menjelaskan ciri khas dari kedua verba tersebut secara struktur termasuk dilihat dari hubungan antara verba suru dan yaru dengan jenis nomina maupun partikel (pemarkah kasus) joshi yang menyertai kemunculannya.

Terkait dengan substitusi di antara kedua verba tersebut, Ogawa (1982: 431432) menyatakan bahwa walaupun verba yaru banyak dianggap sebagai bentuk slang dari verba suru dalam pemakaiannya sehari -hari, bukan berarti kedua verba tersebut dapat selalu saling mensubstitusi pada semua jenis kalimat. Lebih lanjut, Ogawa juga menyatakan bahwa kedua verba tersebut hanya bisa saling mengsubsitusi pada kalimat-kalimat yang mengungkapkan aktifitas umum yang dan memiliki objek nomina yang menyatakan aktifitas kongkret seperti dalam kalimat di bawah ini.

\section{3. a. Suru dakeno koto ha shita.}

melakukan hanya hal Top Melakukan-PAST

"(saya) sudah melakukan hal-hal yang harus saya lakukan"

b. $\underline{\text { Yaru dakeno koto ha yatta. }}$. melakukan hanya hal Top Melakukan-PAST

"(saya) sudah melakukan hal-hal yang harus saya lakukan" 
4. a. yuube osoku made ge-mu o shita.

tadi malam larut sampai game Acc Melakukan-PAST

“Tadi malam saya melakukan/bermain game sampai larut (malam)."

b. yuube osoku made ge-mu o yatta.

tadi malam larut sampai game Acc Melakukan-PAST

“Tadi malam saya melakukan/bermain game sampai larut (malam)."

Selain itu, verba suru dan yaru juga dapat saling mensubstitusi saat bergabung dengan kata tunjuk yang menunjukkan makna 'cara melakukan sesuatu'.

\section{Koushi(yat)tara, hayaku kopii dekiruyo}

Begini melakukan cepat fotokopi bisa

"Kalau (kamu) melakukan (dengan cara) seperti ini, (kamu) dapat

memfotokopinya dengan cepat."

Namun demikian, penjelasan Ogawa (1982) di atas tidak cukup komprehensif dalam membahas kemungkinan berterimanya substitusi antara verba suru dan yaru baik secara gramatikal maupun semantis. Terlepas dari kategorisasi yang dilakukannya terkait keberterimaan subsitusi kedua verba tersebut seperti terlihat pada contoh (3), (4), dan (5), penulis melihat bahwa pada dasarnya kategorisasi tersebut secara makna tidak ada perbedaan sama sekali. Verba suru dan yaru pada ketiga contoh tersebut menunjukkan makna yang sama yaitu 'melakukan sebuah aktifitas kongkret' yang merupakan makna leksikal dasar dari kedua verba tersebut. Oleh karena itu, penulis berpendapat perlu dilakukan analisis yang lebih komprehensif dan mampu mengidentifikasi prasyarat keberterimaan substitusi di antara kedua verba tersebut baik secara struktur maupun maknanya.

\section{METODE PENELITIAN}

Metode penelitian yang digunakan dalam penelitian ini adalah metode deskriptif. Data -data kalimat berpredikat verba suru dan yaru yang dikumpulkan dari sumber data korpus online kotonoha.gr.jp penulis klasifikasikan berdasarkan makna dan strukturnya. Setelah menganalisis ciri khas makna dan struktur kedua verba tersebut, penulis melakukan menyulih verba suru dengan verba yaru dan sebaliknya untuk setiap jenis kalimat untuk mengetahui keberterimaannya baik secara gramatikal maupun semantik.

\section{HASIL DAN PEMBAHASAN}

Seperti telah disinggung sebelumnya, verba suru merupakan verba paling produktif dan paling banyak ditemui penggunaannya dalam kehidupan sehari hari. Hal ini dikarenakan verba tersebut tidak hanya memiliki makna dasar secara leksikal, tetapi juga memiliki makna gramatikal yang dihasilkan melalui verbalisasi kelas kata yang lain, maupun kemunculan verba tersebut dengan unsur partikel joshi tertentu yang menghasilkan makna derivatif yang betul - betul berbeda dengan makna dasarnya. Begitu pun juga halnya dengan verba yaru. Kemunculan verba yaru dengan verba lain dalam pola kalimat tertentu dapat menghasilkan makna derivatif yang berbeda dari makna dasarnya. Atas dasar itulah, penulis membuat klasifikasi 
yang berbeda dengan Nita (1993) untuk menganalisis ciri khas kedua verba tersebut baik secara struktur maupun maknanya. Penulis akan membagi kedua verba tersebut berdasarkan dua kategori yaitu makna leksikal dan makna gramatikal dengan harapan dapat menghasilkan kategori makna verba yang lebih sederhana dan mudah untuk dipahami.

\subsection{Verba Suru}

Melalui penelitian ini penulis menemukan bahwa makna leksikal dari verba suru secara garis besar bisa dibagi menjadi tiga yaitu mengungkapkan makna melakukan sesuatu atas dasar kehendak sendiri (volitionally), menimbulkan gejala fisiologis seperti batuk, bersin, dan sejenisnya, memperlihatkan atau memiliki kulitas tertentu yang terkait dengan segala sesuatu yang menjadi bagian dari tubuh kita, mengubah atau memutuskan sesuatu, dan merasakan hal-hal yang tertangkap oleh panca indera.

6. Yaseru tame ni mainichi jogging o shiteiru.

menjadi kurus untuk setiap hari jogging Acc melakukan

"Saya (melakukan) jogging setiap hari supaya menjadi kurus."

7. Mouretsuna seki o suru.

dahsyat batuk Acc melakukan

"(Melakukan) batuk dengan dahsyat."

8. Inu ga ribbon o shiteiru.

Anjing Nom pita Acc memakai

"Anjing memakai pita."

9. Watashi ha jibun no kodomo o isha ni siyou to omou.

Saya Top sendiri anak Acc Dat menjadikan berpikir

"Saya berpikir untuk menjadikan anak saya seorang dokter."

10. Ayashii oto ga shita.

Mencurigakan bunyi Nom terdengar

"Terdengar bunyi yang mencurigakan."

Data (6), (7), dan (8) pada dasarnya memiliki struktur kalimat yang sama di mana verba mengikat objek langsung yang merupakan nomina yang menunjukkan sebuah aktifitas kongkret dan ditandai dengan partikel $o$ yang merupakan pemarkah objek. Apabila dilihat secara semantis verba suru pada pada kalimat (6) dan (7) memiliki makna leksikal yang sama yaitu melakukan aktifitas kongkret. Namun yang membedakan di antara keduanya adalah pada data (7) yang mengandung makna menimbulkan gejala fisiologis, verba suru akan didahului oleh objek nomina yang bermakna leksikal gejala fisiologi seperti batuk, bersendawa, bersin, dan sejenisnya. Sedikit berbeda dengan data (6) dan (7), verba suru pada kalimat (8) termasuk ke dalam kategori makna memiliki sesuatu kualitas yang terkait dengan segala sesuatu yang menjadi bagian dari tubuh. Verba suru yang menjadi predikat pada kalimat yang menunjukkan makna seperti ini biasanya merupakan segala sesuatu yang melekat dengan tubuh kita baik itu organ tubuh maupun segala sesuatu yang kita gunakan di badan baik berupa asesoris, pakaian, dan sebagainya. Pada data (8) nomina yang menajdi objek adalah pita sehingga makna yang paling tepat untuk verba suru pada kalimat ini adalah memakai. 
Adapun data (9) dan (10) secara struktur memiliki perbedaan dengan kalimat-kalimat sebelumnya. Pada data (9), verba suru didahului dengan pemarkah datif ni. Pemarkah ini menandakan terjadinya perubahan baik itu kondisi, kualitas, maupun wujud fisik sesuatu. Pada kalimat ini, pemarkah ni terikat pada dua argumen yaitu kodomo 'anak' sebagai kondisi awal dan isha 'dokter' sebagai kondisi yang pasca terjadinya perubahan. Makna verba suru pada kalimat ini sendiri termasuk ke dalam kategori makna mengubah atau memutuskan sesuatu, sehingga pada kalimat (9) ini verba suru bermakna mengubah anak menjadi seorang dokter atau menjadikan anak seorang dokter. Pada data (10) verba suru didahului dengan partikel ga yang merupakan pemarkah Subjek. Adapun maknanya sendiri termasuk ke dalam kategori makna merasakan hal-hal yang tertangkap oleh panca indera. Pada kalimat (10), verba suru dimaknai 'terdengar' karena menyesuaikan dengan nomina yang menjadi subyeknya dalam hal ini suara. Selain itu kita juga bisa melihat bahawa walaupun menggunakan yang sama, verba suru pada data (6),(7),(8), dan (9) termasuk ke dalam verba transitif, sedangkan pada data (10) termasuk ke dalam verba intransitif. Berikutnya penulis akan membahas terkait makna gramatikal yang dimiliki oleh verba suru.

Makna gramatikal verba suru tidak bisa terbentuk oleh verba suru itu sendiri, melainkan dikarenakan kemunculan verba tersebut dengan unsur kalimat lain yang membentuk sebuah pola kalimat dengan makna derivasi tertentu. Dari hasil analisis, penulis mengidentifikasi tiga makna gramatikal dari verba suru yaitu yang terkait dengan aspek inchoative, politeness, dan pengandaian. Makna yang pertama ditandai dengan bentuk verba mizenkei yang ditandai dengan akhiran -ou diikuti dengan partikel to dan verba suru $(\mathrm{V}$ mizenkei + to + suru $)$. Pola kalimat ini menghasilkan makna sesaat sebelum sesuatu mulai terjadi atau lebih dalam perspektif aspektualitas termasuk ke dalam kategori aspek inchoative. Makna berikutnya yang terkait dengan unsur politeness atau kesopanan terbentuk dari pola kalimat kenjogo yang merupakan satu varian bahasa sopan dalam bahasa Jepang (keigo). Makna ini ditandai dengan predikat dalam bentuk 「Klitik O + Stem verba + suru」dan berfungsi untuk menunjukkan penghormatan pada lawan bicara dengan memposiskan diri sendiri lebih rendah dari lawan bicara tersebut. Makna gramatikal selanjutnya yaitu pengandaian ditandai dengan pola 「Verba infinitif + partikel to + suru + to」.

11. Kenka o tomeyou to shiteiru. pertengkaran Acc menghentikan "(saya) sedang akan menghentikan pertengkaran itu."

12. Watashitachi ha sensei o dousoukai ni omanekishita. kami Top guru Acc reuni Dat mengundang -Polite-PAST

"Kami mengundang guru ke acara reuni."

13. Moshi ame ga mada furitsuduku to suru to, kawa no teibou ga abunai.

kalau hujan Nom masih terus turun sungai tanggul Nom berbahaya "Seandainya hujan masih turun terus - menerus, tanggul sungai akan (berada dalam keadaan) berbahaya." 


\subsection{Verba Yaru}

Apabila dibandingkan dengan verba suru, penulis menemukan bahwa verba yaru memiliki varian makna leksikal yang lebih banyak. Penulis tidak hanya berhasil mengkonfirmasi teori tentnag makna verba yaru yang telah dikemukan oleh Nita (1993), tetapi penulis juga menemukan satu varian makna leksikal lainnya. Selain makna leksikal menyuruh seseorang ke suatu tempat untuk melalukan sesuatu yang kita inginkan, pergi membawa sesuatu ke suatu tempat, mengarahkan pandangan ke arah tertentu, memberikan sesuatu kepada orang yang lebih muda atau makhluk hidup lainnya, melakukan aktifitas tertentu (termasuk makan dan minum), menyakiti atau menimbulkan kerugian, menjalani hidup, dan makna menderita suatu jenis penyakit, data menunjukkan bahwa verba yaru juga bisa menunjukkan makna mengirim. Meskipun secara semantik verba yaru memiliki varian makna leksikal yang cukup banyak dan beragam, tetapi secara struktur verba yaru yang menjadi predikat sebuah kalimat memiliki ciri khas yang sama. Berbeda dengan verba suru yang bisa dikategorikan ke dalam verba transitif maupun intransitif, verba yaru hanya termasuk ke dalam kategori verba transitif. Hal ini berarti verba yaru senantiasa memiliki objek langsung yang dimarkahi dengan partikel $o$. Yang perlu diperhatikan pada saat menggunakan varian-varian makna dari verba ini, kita harus memastikan bahwa nomina yang menjadi objek langsung sesuai dengan makna yang ingin dibangun. Misalnya untuk makna menderita penyakit, maka objek langsungnya harus merupakan nomina-nomina yang menunjukkan jenis penyakit tertentu. Begitu pun juga untuk mengungkapkan makna mengarahkan pandangan mata ke arah tertentu maka nomina yang bisa menjadi objek langsungnya terbatas pada nomina-nomina yang memiliki kaitan dengan indera penglihatan seperti mata me dan pandangan shisen.

14. Isha o yobi ni yaru.

dokter Acc memanggil Dat menyuruh pergi

"Saya akan menyuruhnya pergi untuk memanggil dokter."

15. Watashi no kaban doko ni yatteno.

Saya tas mana Dat membawa pergi-PAST

"Tasku (kau) bawa pergi ke mana?"

16. Narita o ririku surutoki me o soto ni yaru to chakuriku suru hikouki no akari to heikou shiteita.

Narita Acc lepas landas waktu mata keluar mendarat pesawat lampu sejajar-PAST

"Pada saat lepas landas, dan mengarahkan pandanganku ke luar, (posisiku) sejajar dengan lampu pesawat yang akan mendarat."

17. Inu ni esa o yaru.

anjing Dat makanan hewan Acc memberikan

"(aku) memberikan makanan hewan kepada anjing."

18. Earobiksu o yatteiru

Aerobiks Acc melakukan

"(aku) melakukan senam aerobics."

19. Aitsu o yare.

Dia (kasar) Acc Menyakiti-IMPERATIF

"Hajar dia." 
20. Kare ha kyounen, ikaiyou o yatta.

Dia (lk) Top tahun lalu, tukak lambung Acc menderita

"Tahun lalu, dia menderita penyakit tukak lambung."

21. Watashi ha maishuu Kazoku ni tegami o yarimasu.

Saya Top setiap minggu keluarga Dat surat Acc mengirim

"saya selalu mengirim surat kepada keluarga setiap minggu."

Adapun untuk makna gramatikal verba yaru penulis hanya menemukan dua varian makna yaitu memutuskan atau bertekad untuk melakukan sesuatu dan melakukan sesuatu untuk orang lain. Meskipun mengungkapkan makna yang berbeda, tetapi secara struktur kedua makna tersebut dibentuk dari gabungan verba yaru dengan verba lainnya dalam bentuk -teyaru sebagaimana terlihat pada contoh di bawah ini.

22. Soudana. sassato koroshiteyarouka.

Benar juga, cepat bunuh

"Benar juga, ayo kita cepat bunuh saja,"

23. kodomo ni kutsu o katteyatta.

anak Dat sepatu Acc membelikan

"Membelikan sepatu untuk anak."

\subsection{Substitusi antara Verba Suru dan Yaru}

Hasil analisis pada penelitian ini menunjukkan bahwa substitusi antara verba suru dan verba yaru yang dapat dilakukan tanpa mengubah makna dari kalimat itu sendiri hanya terbatas pada dua jenis kalimat saja. Yang pertama adalah kalimat di mana verba suru dan yaru menunjukkan makna melakukan suatu aktifitas kongkret yang sifatnya umum, termasuk di dalamnya melakukan jenis pekerjaan tertentu seperti dapat kita lihat pada data (4). Yang kedua, verba-verba tersebut juga dapat saling mensubstitusi pada kalimat yang menyatakan makna menderita penyakit sebagaimana bisa kita lihat pada kalimat (20) dan (24) dikarenakan kedua verba tersebut pada dasarnya memiliki makna leksikal yang sama yaitu menderita sebuah penyakit.

24. Sakunen, chichi ha omoi byouki o shita.

tahun lalu, ayah Top berat penyakit Acc menderita

"Tahun lalu, ayah menderita penyakit yang berat."

Yang sedikit berbeda dengan penelitian Ogawa (1982), melalui penelitian ini penulis juga menemukan bahwa pada kalimat dengan beberapa struktur tertentu, kedua verba ini bisa saling mensubstitusi tetapi menimbulkan perbedaan makna di anatara keduanya. Yang pertama adalah pada saat verba tersebut menjadi muncul dalam kalimat Bersama kata sifat, dan yang kedua adalah pada saat kedua verba tersebut menjadi verbalisator onomatope gitaigo. Perhatikan contoh - contoh kalimat di bawah ini. 
25. a. Shiken o yasashiku shita.

ujian Acc mudah membuat jadi

"Mempermudah (membuat jadi lebih mudah) ujian."

b. Shiken o yasshiku yatta.

ujian Acc mudah melakukan

"Mengerjakan ujian dengan mudah."

26. a. Sakana no kuchi ga pakupaku shita

ikan mulut Nom terbuka dan tertutup

"Mulut ikan membuka dan menutup."

b. Sakana ha kuchi o pakupaku yatta.

ikan Top mulut Acc membuka dan menutup

"Ikan membuka dan menutup mulutnya (berulang-ulang)

Pada data (25a), penggunaan verba suru dimaksudkan untuk mengungkapkan makna mengubah kondisi soal ujian dari sulit menjadi lebih mudah. Sedangkan pengsubstitusian verba suru oleh verba yaru pada kalimat (25b), mengubah makna awalnya menjadi melakukan ujian dengan mudah. Hal ini dikarenakan pada verba yaru tidak memiliki makna leksikal mengubah kondisi atau kualitas tertentu, sehingga ajektiva mudah pada kalimat tersebut tidak merujuk pada kualitas soal ujian melainkan bagaimana cara si penutur mengerjakan soal ujian tersebut. Kemudian pada data (26a) dan (26b), kita juga bia melihat bahwa walaupun kedua verba bisa menjadi verbalisator bagi onomatope gitaigo. Akan tetapi secara struktur kedua kalimat tersebut berbeda. Verba suru pada kalimat tersebut merupakan verba intransitif yang menerangkan kondisi mulut ikan pada saat itu, sedangkan pada kalimat (26b) verba yaru membentuk verba transitif yang menerangkan aktifitas yang dilakukan oleh ikan tersebut yaitu membuka dan menutup mulutnya secara berulang-ulang.

\section{PENUTUP}

Melalui penelitian ini, penulis berhasil menemukan bahwa pada dasarnya baik verba suru dan verba yaru memiliki lebih dari satu varian makna, dan di antaranya ada yang beririsan sehingga memungkinkan verba suru dan verba yaru untuk saling mengsubtitusi tanpa mengubah makna yang ingin disampaikan melalui kalimat tersebut. Namun demikian, substitusi kedua verba tersebut hanya dimungkinkan pada kalimat-kalimat di mana kedua verba tersebut digunakan dalam kalimat yang ingin menyampaikan makna yang sesuai dengan makna lekikal yang dimilikinya. Selain itu, penulis juga menemukan bahwa ada kalanya kedua verba tersebut dapat saling mensubstitusi dalam sebuah konstruksi kalimat yang sama namun menghasilkan makna yang berbeda

\section{DAFTAR PUSTAKA}

Akamatsu, Ken. 2001. Rabu Hina. Tokyo : Kodansha

Fujiwara Masanori. 1990. A Course In Modern Japanese. Nagoya : Nagoya daigaku Shuppankai

Fujiwara Masanori. 1999. Yoku Wakaru Bunpo. Tokyo: Aruku 
Inu Isnaeni Sidiq, Erlina Zulkifli Mahmud, Taufik Ampera

Kuno, Susumo . 1973. The Structure Of The Japanese Language. London : The MIT Press

Nita Yoshio. 1993. Nihongo no Kaku o Megutte. Tokyo : Kuroshio Shuppan Ogawa Yoshio.1982. Textual Nihongo Kyouiku Jiten. Tokyo: Taishuukan Shoten

Suratman, Maman. 2001. Verbalisasi Dengan Suffiks - Suru Dalam Bahasa Jepang. Tesis: FIB UNPAD

Sutedi, Dedi. 2003. Dasar-dasar Linguistik Bahasa Jepang. Bandung : HUP

Suzuki. 1972. Nihongo Bunpo to Keitairon. Tokyo : 3A Network. 